\title{
Changes in hydrogeological properties of the River Choushui alluvial fan aquifer due to the 1999 Chi-Chi earthquake, Taiwan
}

\author{
Cheng-Shin Jang • Chen-Wuing Liu • Yeeping Chia • \\ Li-Hsin Cheng • You-Ching Chen
}

\begin{abstract}
Changes in hydrogeological properties of the River Choushui alluvial fan aquifer before and after the 1999 Chi-Chi earthquake, Taiwan, have been identified using pumping tests. Three wells, SH2, YL2 and SC2, located in a compressional zone with high coseismic groundwater levels, were tested. The threshold of the aquifer deformation with respect to transmissivity $(T)$ is greater than that with respect to storage coefficient $(S)$. Decreases in the post-earthquake $\mathrm{S}$ are approximately $60 \%$ at $\mathrm{SH} 2$ and $\mathrm{SC} 2$, indicating aquifer compression after the Chi-Chi earthquake. Changes in the post-earthquake $T$ range from $61 \%$ increase to $0.8 \%$ decrease. Moreover, results from anisotropy analysis of $T$ at $\mathrm{SC} 2$ further illustrate that normal stresses induced by the Chi-Chi earthquake have consolidated soil particles. Soil particles dilated laterally after the earthquake, resulting in an increase of the equivalent $T$. The changes in hydrogeological properties have a considerable influence on spatiotemporal fluid pressure and horizontal groundwater movement, resulting in different amounts of drawdown during post-earthquake pumping.
\end{abstract}

Received: 6 April 2007 / Accepted: 2 October 2007

Published online: 10 November 2007

(C) Springer-Verlag 2007

\section{C.-S. Jang}

Department of Leisure and Recreation Management, Kainan University,

Luzhu, Taoyuan, Taiwan 33857, Republic of China

C.-W. Liu $(\bowtie) \cdot$ Y.-C. Chen

Department of Bioenvironmental Systems Engineering,

National Taiwan University, Taipei, Taiwan 10617,

Republic of China

e-mail: lcw@gwater.agec.ntu.edu.tw

Tel.: +886-2-23626480

Fax: $+886-2-23639557$

Y. Chia

Department of Geosciences,

National Taiwan University, Taipei, Taiwan 10617, Republic of China

L.-H. Cheng

Department of Occupational Safety and Hygiene,

Fooyin University, Kaohsiung Hsien, 831 Taiwan, Republic of China
Résumé Les changements des propriétés hydrogéologiques de l'aquifère des dépôts alluviaux de la rivière Choushui, avant et après le tremblement de terre de Chi-Chi en 1999 à Taiwan, ont été identifiés par essais de pompages. Trois puits, SH2, YL2 et SC2, localisés dans une zone de compression avec des niveaux d'eaux souterraines co-sismiques élevés, ont été testés. Le seuil de déformation de l'aquifère selon la transmissivité (T) est plus important que selon le coefficient d'emmagasinement $(S)$. Les valeurs de Saprès le séisme ont diminué de $60 \%$ au niveau de $\mathrm{SH} 2$ et de $\mathrm{SC} 2$, ce qui indique une compression de l'aquifère après le séisme de Chi-Chi. Les changements de $T$ sont compris entre une augmentation de $61 \%$ et une diminution de $0.8 \%$. De plus, les résultats de l'analyse de l'anisotropie de $T$ dans le SC2 illustrent que les tensions perpendiculaires induites par le séisme de Chi-Chi ont consolidé les particules du sol. Les particules de sol se sont dilatées latéralement à la suite du séisme, résultant en une augmentation de la transmissivité équivalente. Les changements des propriétés hydrogéologiques ont une influence considérable sur la pression spatio-temporelle des fluides et sur les mouvements horizontaux des eaux souterraines, ce qui se traduit par des amplitudes de rabattement différentes lors des essais de pompages menés après le séisme.

Resumen Mediante pruebas de bombeo, se han identificado cambios en las propiedades hidrogeológicas del acuífero del abanico aluvial del Río Choushui, antes y después terremoto de Chi-Chi, Taiwán, en 1999. Se hicieron pruebas en tres pozos, SH2, YL2 y SC2, localizados en una zona compresiva con niveles cosísmicos altos de agua subterránea. El valor umbral de la deformación en el acuífero con respecto a la transmisividad $(T)$ es mayor que respecto al coeficiente del almacenamiento $(S)$. Las disminuciones en el valor de $S$, post-terremoto están aproximadamente en $60 \%$ en SH2 y $\mathrm{SC} 2$, indicando compresión del acuífero después del terremoto de Chi-Chi. Los cambios post-terremoto en $T$, van desde un aumento del $61 \%$ a una disminución del $0.8 \%$. Es más, los resultados del análisis de anisotropía de $T$ en SC2, ilustran mejor que las tensiones normales inducidas por el terremoto de Chi-Chi han consolidado las partículas del terreno. Las partículas del terreno se dilataron lateralmente después del terremoto, produciendo un aumento de $T$ equivalente. Los cambios en las 
propiedades hidrogeológicas tienen una influencia considerable en la presión espacio-temporal del fluido y en el movimiento horizontal del agua subterránea, produciendo cantidades diferentes de abatimiento durante el bombeo post-terremoto.

Keywords Taiwan - Earthquake Pumping test . Transmissivity · Storage coefficient

\section{Introduction}

On 21 September 1999, an earthquake of $\mathrm{M}_{\mathrm{L}} 7.3$ ( $\mathrm{M}_{\mathrm{W}}$ 7.6; moment magnitude and Richter magnitude, respectively) occurred in Chi-Chi town in central Taiwan, and caused a rupture along the Chelungpu fault (Fig. 1). The earthquake epicenter was at $23.85^{\circ} \mathrm{N}, 120.82^{\circ} \mathrm{E}$, and had a hypocentral depth of roughly $8 \mathrm{~km}$. The occurrence of the earthquake caused rapid changes in crust strains. Groundwater levels which fluctuated with the changes in crust strains are termed "coseismic" groundwater levels. A groundwater- monitoring network in the River Choushui alluvial fan aquifer, comprising 70 hydrogeological stations and 188 groundwater-monitoring wells, also recorded coseismic groundwater levels during the Chi-Chi earthquake (Chia et al. 2001). The coseismic groundwater levels ranged from rising $7.42 \mathrm{~m}$ to falling $11.09 \mathrm{~m}$ (Water Conservancy Agency of Taiwan 2000). Generally, the falling coseismic groundwater levels have been found between the Changhua fault and the Chelungpu fault, indicating an extensional zone of the crust, whereas the rising coseismic groundwater levels have been located west of the Changhua fault, representing a compressional zone of the crust (Lee et al. 2002).

Hydrogeological parameters, such as storage coefficient $(S)$, hydraulic conductivity $(K)$ and transmissivity $(T)$, are important parameters for groundwater modeling and management. The parameters are related to changes in coseismic groundwater levels and pore pressure dissipation (Roeloffs 1996; Lin et al. 2004). A big earthquake leads to tremendous changes in crustal strains and stresses. Earthquakes can produce changes in hydro-

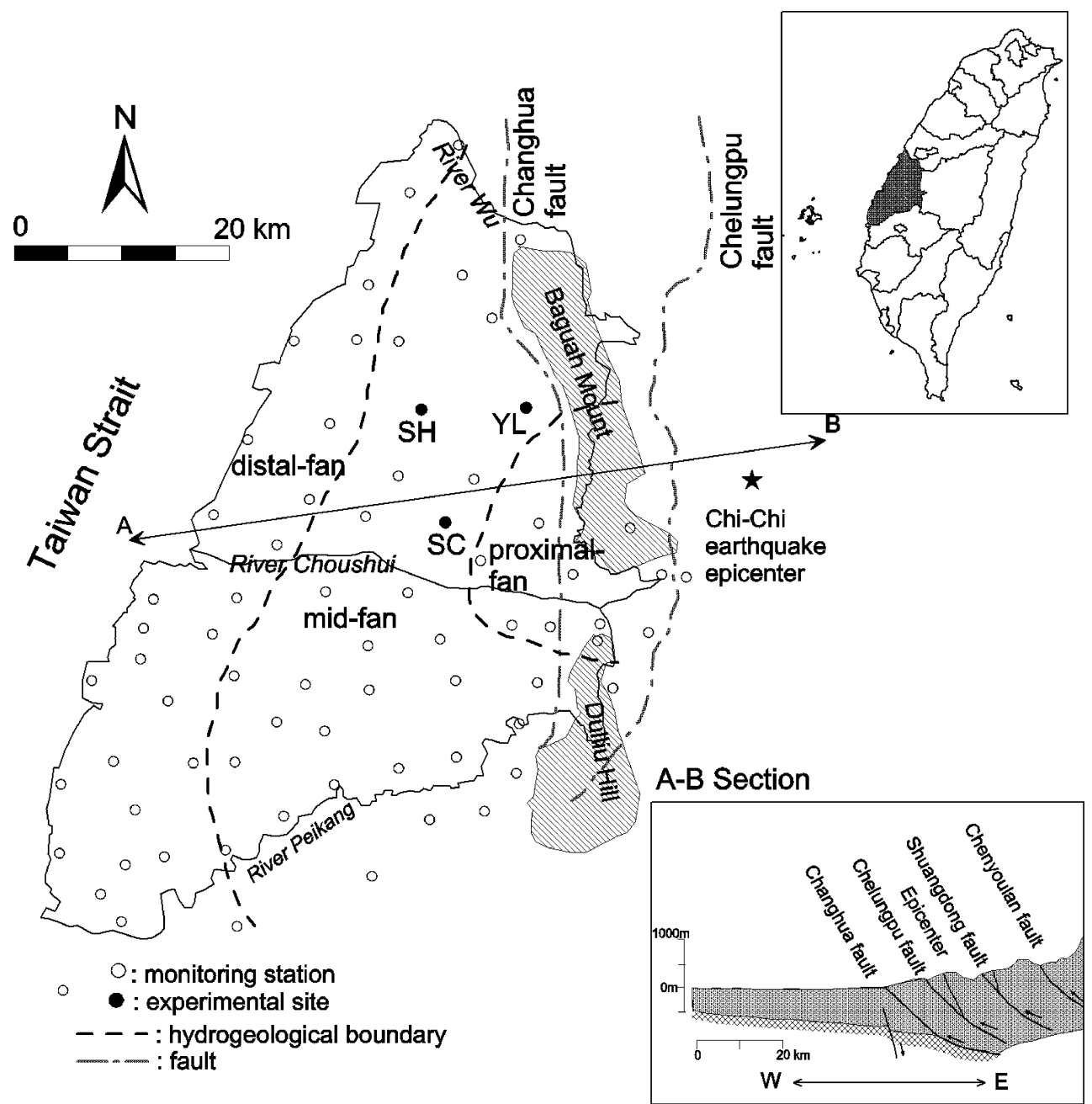

Fig. 1 Study area (shaded region indicated in the index map of Taiwan) and experimental sites for pumping tests. Cross-section $A-B$ also shown 
geological properties. Montgomery and Manga (2003) proposed that a sustained change in groundwater levels induced by an earthquake reflects nonrecoverable deformation of aquifer properties, such as changes in $S, K$ and porosity. Tokunaga (1999) utilized a numerical groundwater model equipped with an optimization method to analyze changes in $\mathrm{K}$ and specific yield $\left(S_{\mathrm{y}}\right)$ due to the 1995 Kobe earthquake in Japan. Tokunaga estimated that the $K$ after the earthquake increased by a minimum $500 \%$ over that before the earthquake. The $S_{\mathrm{y}}$ was in the range $0.3-1.7 \%$ after the Kobe earthquake but Tokunaga did not report the measurement of the pre-earthquake $S_{\mathrm{y}}$. Additionally, coseismic groundwater levels can indicate a static volumetric strain on the crust during an earthquake (Roeloffs 1996). Wang et al. (2001) proposed a model associated with change in soil porosity during the 1999 Chi-Chi earthquake; their estimated change in soil porosity ranged from $10^{-6}$ to $10^{-7}$. Yu et al. (2001) measured minor coseismic subsidence $(<0.3 \mathrm{~m})$, using a global positioning system (GPS), across the River Choushui alluvial fan. According to their analytical outcomes for changes in soil porosity and coseismic subsidence, Hsu and Tung (2005) quantified the changes in $K$ and porosity resulting from the 1999 Chi-Chi earthquake; they reported a maximum reduction in $K$ of $0.01 \%$, estimated/based on change in soil porosity, and that of $1.5 \%$, estimated/based on coseismic subsidence. Both estimated methods indicated a minor reduction in the maximum $K$.

A pumping test is a common tool for determining aquifer parameters $T$ and $S$. This approach has been used to examine post-earthquake aquifer parameters (Brodsky et al. 2003; Doan et al. 2006). Brodsky et al. (2003) performed a pumping test at a well near Grants Pass, Oregon, USA, in 2001 (post-earthquake) and revealed that drawdown data were identical to a 1981 test. Their findings showed that the aquifer parameters did not vary as a result of distant $(>100 \mathrm{~km})$ earthquakes. Doan et al. (2006) focused on the hydraulic diffusivity $(D, D=T / S)$ along the active Chelungpu fault zone after the 1999 Chi-Chi earthquake. Their study did not demonstrate any variations of hydraulic diffusivity before and after the earthquake. Therefore, previous research has yielded little impetus for attention on field measurements associated with potential changes in hydrogeological properties before and after an earthquake.

Owing to extreme variation of the crust stress and strain during a big earthquake, nonrecoverable and permanent changes in hydrogeological properties are possible. It was hypothesized, as part of this study, that hydrogeological parameters associated with the River Choushui alluvial fan aquifer would change after the 1999 Chi-Chi earthquake when the crust stress and strain exceeded a certain threshold of soil deformation. This work examined these aquifer parameters. Moreover, the analysis of an anisotropic hydrogeological parameter, performed in a four-well pumping system, gave an insight into the influence of the earthquake upon the aquifer properties.

\section{Materials and methods}

\section{Study area and hydrogeology}

The River Choushui alluvial fan is located on Taiwan's west coast. The fan is enclosed by the Taiwan Strait to the west, the River $\mathrm{Wu}$ to the north, the Dulliu Hill and Baguah Mount to the east, and the River Peikang to the south (Fig. 1). The alluvial fan is roughly $1,800 \mathrm{~km}^{2}$ and partitioned into proximal-fan, mid-fan and distal-fan areas according to its hydrogeological condition. Unconsolidated sediments beneath the alluvial fan are from the late Quaternary age and contain abundant groundwater.

Hydrogeological analysis to a maximum depth of approximately $300 \mathrm{~m}$ divided fan deposits into eight overlapping sequences (four marine sequences and four non-marine sequences) in the distal-fan and mid-fan areas (Central Geological Survey of Taiwan 1999a). Nonmarine sequences containing coarse sediments ranging from gravel to sand with high permeability are considered as aquifers, whereas marine sequences containing fine sediments ranging from clay to mud with low permeability are regarded as aquitards (Fig. 2). The proximal-fan area is an unconfined aquifer. Aquitards are located mainly in the distal-fan and mid-fan areas, and not in the proximal-fan area. The aquifer is recharged primarily in the proximal-fan area. The four aquifers from top to bottom are labeled as aquifer 1, aquifer 2, aquifer 3 and aquifer 4, as shown in Fig. 2. The upper aquifer (aquifer 1 ) is an unconfined aquifer and the remaining aquifers in the mid- and distal-fan areas are confined.

\section{Pumping test}

Pumping tests were performed at three sites, stations YanLin (YL), Shi-Hu (SH) and Shi-Chou (SC) in September 2004 (Fig. 1). Each station has 3-4 monitoring wells and each monitoring well is screened at only one depth (Fig. 3). Monitoring wells with a large coseismic groundwater level occurred during the 1999 Chi-Chi

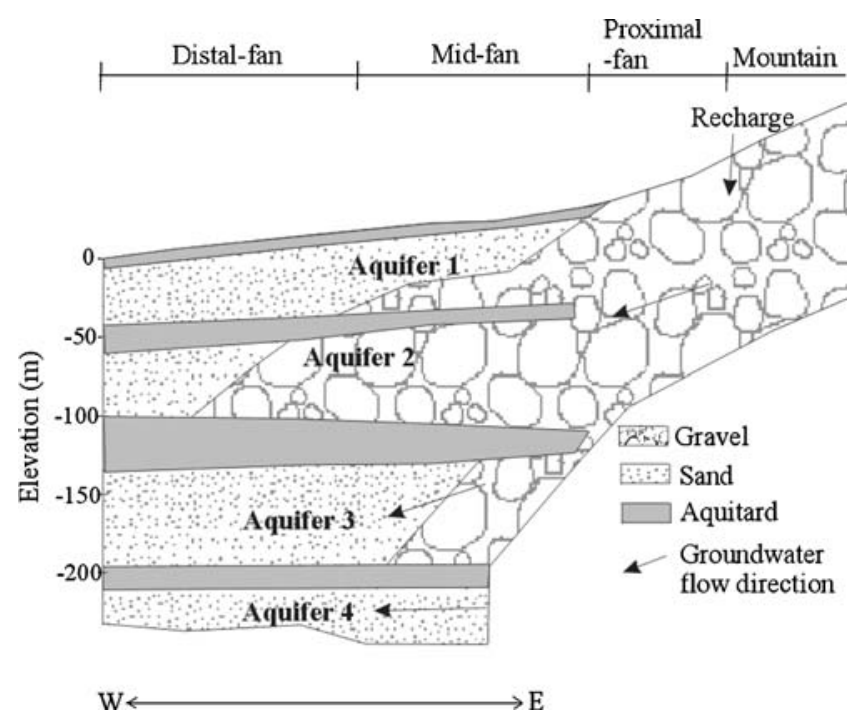

Fig. 2 Hydrogeological profile along the A-B section of Fig. 1 


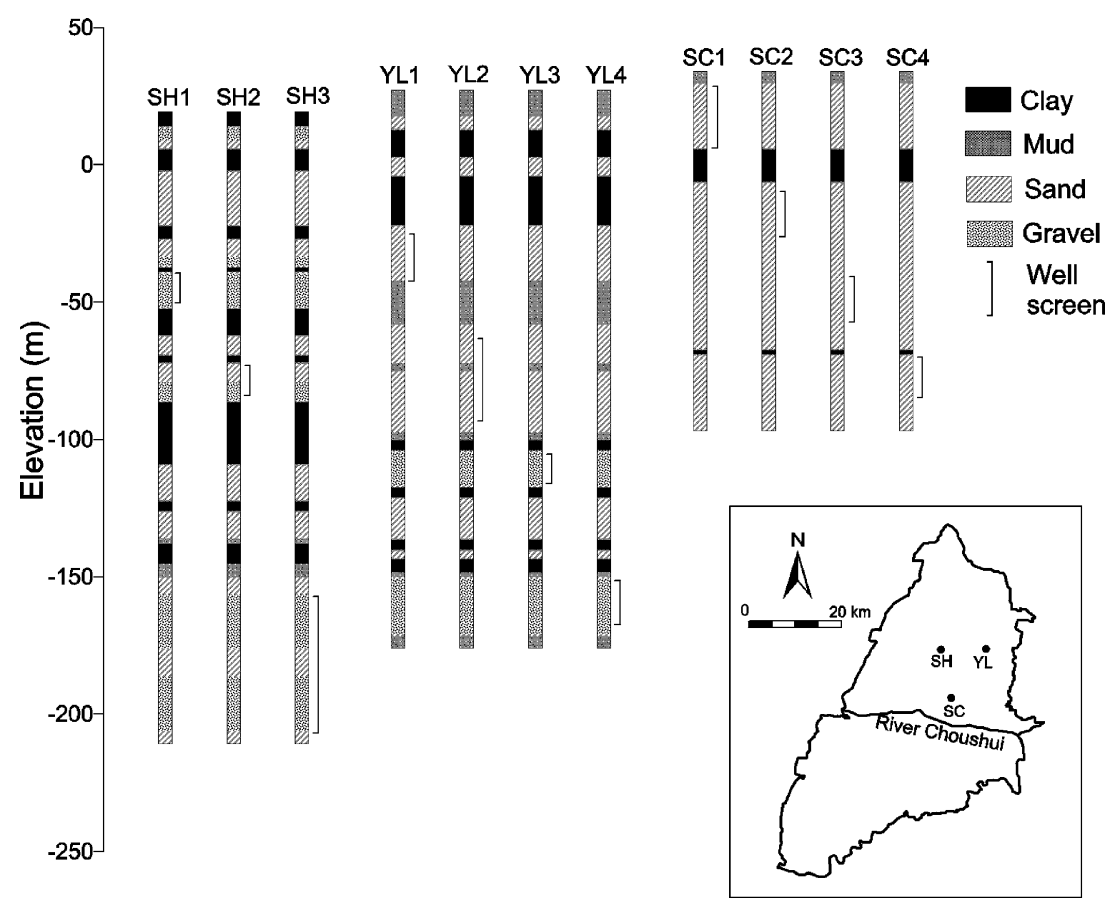

Fig. 3 Stratigraphy in boreholes at the three stations Yan-Lin $(Y L)$, Shi-Hu $(S H)$ and Shi-Chou $(S C)$, located within the study area (delineated in Fig. 1)

earthquake were selected at each station. Accordingly, pumping tests were carried out in wells YL2, SH2 and $\mathrm{SC} 2$, located in confined aquifers ( $\mathrm{SH} 2$ and $\mathrm{SC} 2$ in aquifer 2 , and YL2 in aquifer 3). The depths of wells YL2, SH2 and $\mathrm{SC} 2$ are 121, 106 and $64 \mathrm{~m}$, respectively, and each well is $15 \mathrm{~cm}$ in diameter. Owing to crust compression, the coseismic wellheads in YL2, SH2 and SC2 rose to $6.46,4.76$ and $5.59 \mathrm{~m}$ respectively, during the ground shaking of the 1999 Chi-Chi earthquake. Widespread liquefaction of the ground surface was reported in the alluvial fan during the earthquake, especially in the area of YL (Wang et al. 2001, 2003; Lin et al. 2004).

Because of a lack of other suitable monitoring wells, water pumping and water level monitoring were conducted simultaneously at well YL2. Wells SH2 and SC2 were used solely for pumping water. One observation well was located near the $\mathrm{SH} 2$ well at a distance of $18.3 \mathrm{~m}$. Three observation wells, SC2-1, SC2-2 and SC2-3, were located near well SC2 at distances of 5.3, 12.3 and $15.8 \mathrm{~m}$, respectively, and together, these four wells comprised a four-well monitoring system (the only such system in the current Taiwan groundwater monitoring network). Drawdown data were recorded digitally using HERMIT 3000 (In-Situ Inc., Wyoming, US). Furthermore, the four-well system at SC2 was capable of estimating aquifer anisotropy (Batu 1998).

A modified Theis equation, developed by Cooper and Jacob (1946), was employed to calculate $T$ and $S$ values and expressed as follows:

$Z=\frac{2.3 Q}{4 \pi T} \log \left(\frac{2.25 T t}{r^{2} S}\right)$ where $Z$ is the drawdown; $Q$ is the pumping rate; $r$ is the distance from the observation well to the pumped well; and $t$ is the elapsed pumping time. The $Z$ and $t$ were plotted on semi-logarithm paper. The $T$ values were computed at the wells based on the slope per log cycle. The isotropic $T$ values were obtained at YL2 and SH2. The anisotropic $T$ tensor at $\mathrm{SC} 2$ was acquired from the four-well pumping system (Papadopulos 1965). The twodimensional tensor of $T$ and its equivalent $T\left(T_{\mathrm{e}}\right)$ were defined as follows:

$$
T=\left[\begin{array}{ll}
T_{\mathrm{xx}} & T_{\mathrm{xy}} \\
T_{\mathrm{xy}} & T_{\mathrm{yy}}
\end{array}\right]
$$

$T_{e}=\left(T_{x x} T_{y y}-T_{x y}^{2}\right)^{\frac{1}{2}}$

Figure 4 displayed the arrangement of the four-well pumping system at $\mathrm{SC} 2$. The $\mathrm{x}$ - and $\mathrm{y}$-coordinates at this pumping system were western and southern directions, respectively. The calculation process of the anisotropic $T$ followed Papadopulos (1965) and Batu (1998) in this study.

During 1993 and 1994, the Water Conservancy Bureau of Taiwan (1995) conducted pumping tests at the three monitoring wells SH2, YL2 and SC2, and determined $T$ and $S$ values. For the purposes of this study, the $T$ and $S$ values obtained by the Water Conservancy Bureau of Taiwan (1995) were taken as the hydrogeological properties before the 1999 Chi-Chi earth- 


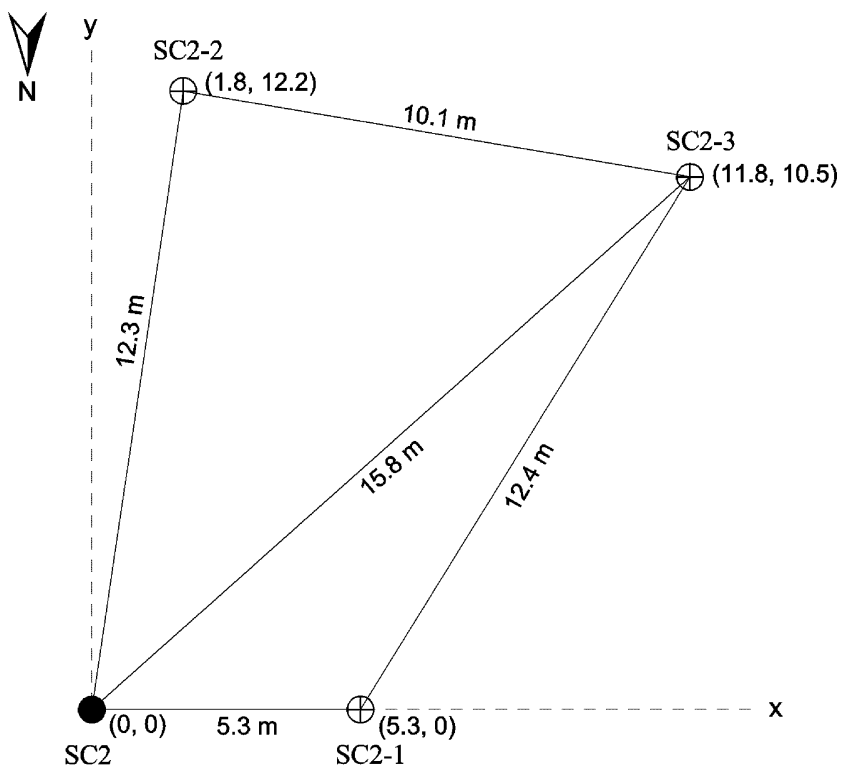

- Pumped well $\oplus$ Observation well

Fig. 4 Arrangement of pumped and observation wells at SC2. The two values in parenthesis indicate the $\mathrm{x}$-coordinate and $\mathrm{y}$-coordinate of wells in meters

quake. The pre- and post-earthquake pumping rates were 60.4, 54.6 and $65.1 \mathrm{~m}^{3} / \mathrm{h}$ for $\mathrm{SH} 2, \mathrm{YL} 2$ and $\mathrm{SC} 2$, respectively. To minimize the difference between the pre- and post-earthquake pumping tests, the same analysis method was employed to address drawdown data. Additionally, after the Chi-Chi earthquake, the Water Resource Bureau of Taiwan (2000) performed an inspection of the monitoring wells using a borehole television inspection technique, indicating that the three wells were not damaged by the earthquake. During the pumping tests, extracted groundwater remained clear, demonstrating that fine sediment had not accumulated in the wells. The locations of the wells also meant that earthquake damage to the wells themselves would be unlikely to affect the study results.

\section{Results}

Figure 5 displayed drawdown data obtained from pumping tests and their fitted lines before and after the earthquake. The drawdown during the post-earthquake pumping tests was greater than that of the pre-earthquake pumping tests at SH2 (Fig. 5a). However, the drawdown during the post-earthquake pumping tests was smaller than that of the pre-earthquake pumping tests at YL2 (Fig. 5b). Unfortunately, the Water Conservancy Bureau of Taiwan (1995) did not report the pre-earthquake original pumping data for SC2-1, SC2-2 and SC2-3. According to the slopes of time/drawdown data, and calculated $S$ and $T$ at the three observation wells documented in their report, the preearthquake fitted lines could be estimated, as shown in Fig. $5 \mathrm{c}-$ e. Additionally, the post-earthquake pumping test at SC2-3 presented a three-step drawdown data (Fig. 5e), indicating that minor fractures or cavities occur in the vicinity of SC2-3.

Because non-linear behavior frequently occurred in the drawdown data that represents the final stages of pumping tests, due to boundary conditions, fitted lines were mainly determined for drawdown data recorded within $100 \mathrm{~min}$. The post-earthquake fitted criteria were consistent with the pre-earthquake criteria used by the Water Conservancy Bureau of Taiwan (1995). The slope of the post-earthquake fitted line is slightly greater than that of the pre-earthquake fitted line at $\mathrm{SH} 2$, but smaller than the slope of the pre-earthquake fitted lines at YL2, SC2-1, SC2-2 and SC2-3. The discrepancy between the pre- and post-earthquake fitted slopes equates to changes in $T$.

Table 1 listed analyzed results associated with $T$ and $S$ before and after the earthquake. At $\mathrm{SH} 2$, the postearthquake $T$ and $S$ are smaller than the pre-earthquake $T$ and $S$, with decreases of 0.8 and $60.1 \%$, respectively; the rather small change in $T$ can be considered as no change. At YL2, the post-earthquake $T$ remarkably exceeds preearthquake $T$, an increase of $60 \%$. However, $S$ is not available for this well.

Table 1 Variations of $T$ and $S$ before and after the 1999 Chi-Chi earthquake

\begin{tabular}{|c|c|c|c|c|c|c|}
\hline \multirow[t]{3}{*}{ Parameters } & \multicolumn{6}{|l|}{ Wells } \\
\hline & \multirow[t]{2}{*}{$\overline{\mathrm{SH}} 2$} & \multirow[t]{2}{*}{ YL2 } & \multicolumn{4}{|l|}{$\mathrm{SC} 2$} \\
\hline & & & $\mathrm{xx}^{\mathrm{c}}$ & $y^{d}$ & $x y^{e}$ & Equivalent \\
\hline $\begin{array}{l}T_{\text {before }}{ }^{\mathrm{a}}\left(\mathrm{m}^{2} / \mathrm{min}\right) \\
T_{\text {after }}\left(\mathrm{m}^{2} / \mathrm{min}\right) \\
\left(T_{\text {after }}-T_{\text {before }}\right) / T_{\text {before }} \times 100 \% \\
S_{\text {before }} \\
S_{\text {after }} \\
\left(S_{\text {after }}-S_{\text {before }}\right) / S_{\text {before }} \times 100 \%\end{array}$ & $\begin{array}{l}0.239 \\
0.237 \\
-0.8 \\
1.51 \times 10^{-4} \\
6.03 \times 10^{-5} \\
-60.1\end{array}$ & $\begin{array}{l}0.59 \\
0.95 \\
61.0 \\
\mathrm{NA}^{\mathrm{f}} \\
\mathrm{NA} \\
\mathrm{NA}\end{array}$ & $\begin{array}{l}1.86 \\
1.18 \\
-36.6 \\
\text { NA } \\
\text { NA } \\
\text { NA }\end{array}$ & $\begin{array}{l}1.97 \\
5.88 \\
198.5 \\
\text { NA } \\
\text { NA } \\
\text { NA }\end{array}$ & $\begin{array}{l}0.15 \\
-0.93 \\
-720 \\
\text { NA } \\
\text { NA } \\
\text { NA }\end{array}$ & $\begin{array}{l}1.91 \\
2.46 \\
28.8 \\
1.48 \times 10^{-3} \\
5.78 \times 10^{-4} \\
-60.4\end{array}$ \\
\hline
\end{tabular}

${ }^{\mathrm{a}}$ Before the earthquake

${ }^{\mathrm{b}}$ After the earthquake

${ }^{\mathrm{c}} x x \mathrm{xx}$-directional tensor

$\mathrm{d} y y$ yy-directional tensor

${ }^{\mathrm{e}} x y$ xy-directional tensor

${ }^{\mathrm{f}} \mathrm{NA}$ not-available 


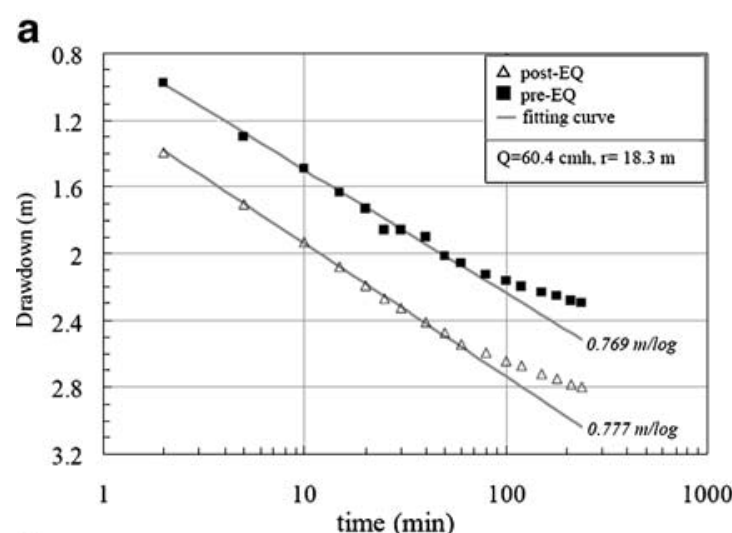

C

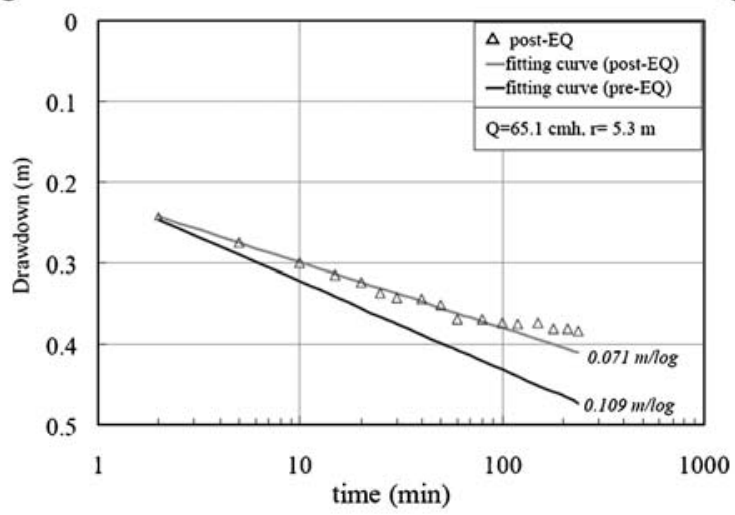

b

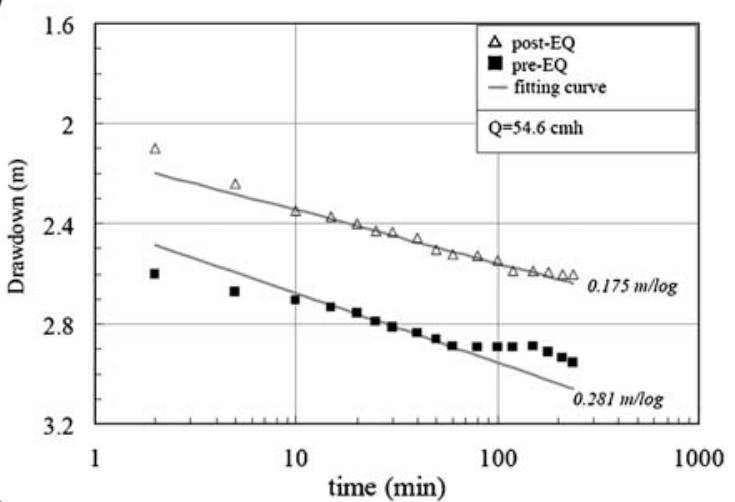

d

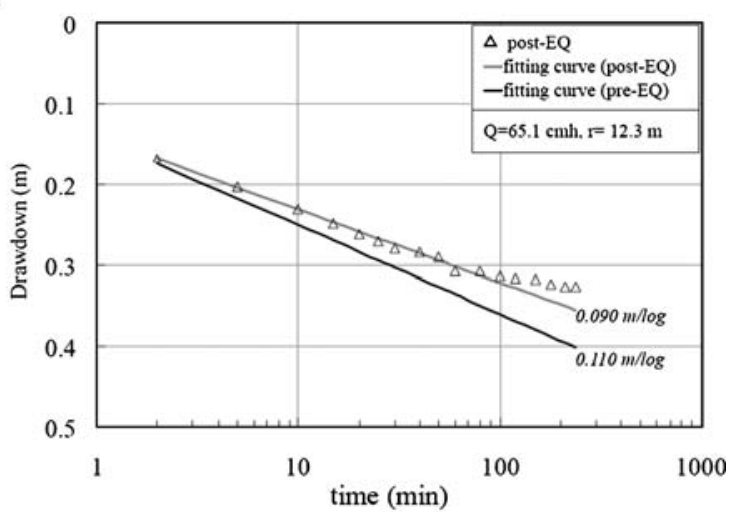

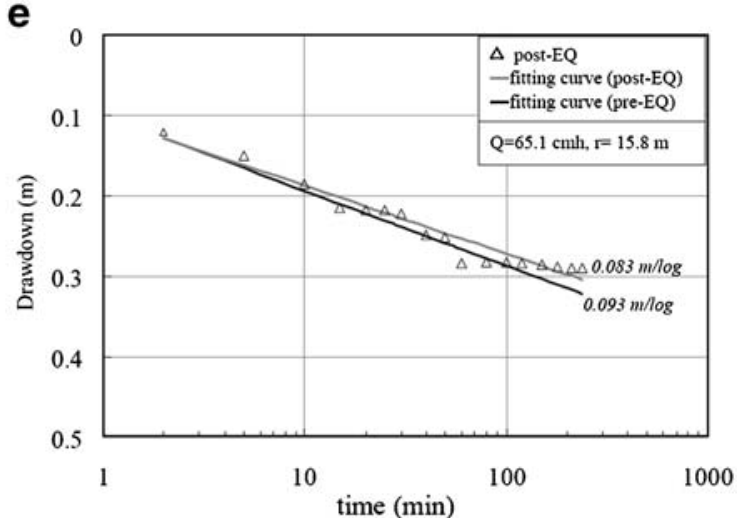

Fig. 5 Comparison of pumping test data before and after the Chi-Chi earthquake (EQ). Data shown for a SH2, b YL2, c SC2-1, d SC2-2, and e SC2-3. The pre-EQ pumping data for SC2-1, SC2-2 and SC2-3 are not available. The fitting curves are drawn according to the slopes of time/drawdown data, and the calculated $S$ and $T$ reported by the Water Conservancy Bureau of Taiwan $(1995) . \mathrm{cmh}^{2} \mathrm{~m} / \mathrm{h}$

At SC2, an average slope for SC2-1, SC2-2 and SC2-3, displayed in Fig. $5 \mathrm{c}-\mathrm{e}$ ), was used to compute the anisotropic $T$ tensors (Batu 1998). However, the Water Conservancy Bureau of Taiwan (1995) did not determine the anisotropic $T$ tensor from the four-well pumping system. Instead, the Water Conservancy Bureau of Taiwan (1995) individually analyzed $S$ and $T$ at the three observation wells. This work used the slopes of time/ drawdown data, and $S$ and $T$ at the three wells to determine pre-earthquake zero-drawdown time scales. When the drawdown was zero, the $t_{0}$ values of SC2-1, SC2-2 and SC2-3 were 0.007, 0.01 and $0.05 \mathrm{~min}$, respectively, for the post-earthquake and were $0.01,0.05$ and $0.08 \mathrm{~min}$, respectively, for the pre-earthquake. The pre- and post-seismic anisotropic $T$ tensors at $\mathrm{SC} 2$ are reported as follows:

$$
\begin{aligned}
& T_{\text {before }}=\left[\begin{array}{ll}
1.86 & 0.15 \\
0.15 & 1.97
\end{array}\right] \\
& T_{\text {after }}=\left[\begin{array}{cc}
1.18 & -0.93 \\
-0.93 & 5.88
\end{array}\right]
\end{aligned}
$$

The pre- and post-seismic equivalent $T$ values computed from Eq. (3) are 1.91 and $2.46 \mathrm{~m}^{2} /$ day, respectively. The post-earthquake $T_{\mathrm{yy}}$ and $T_{\mathrm{e}}$ increase 198.5 and $28.8 \%$ 
a

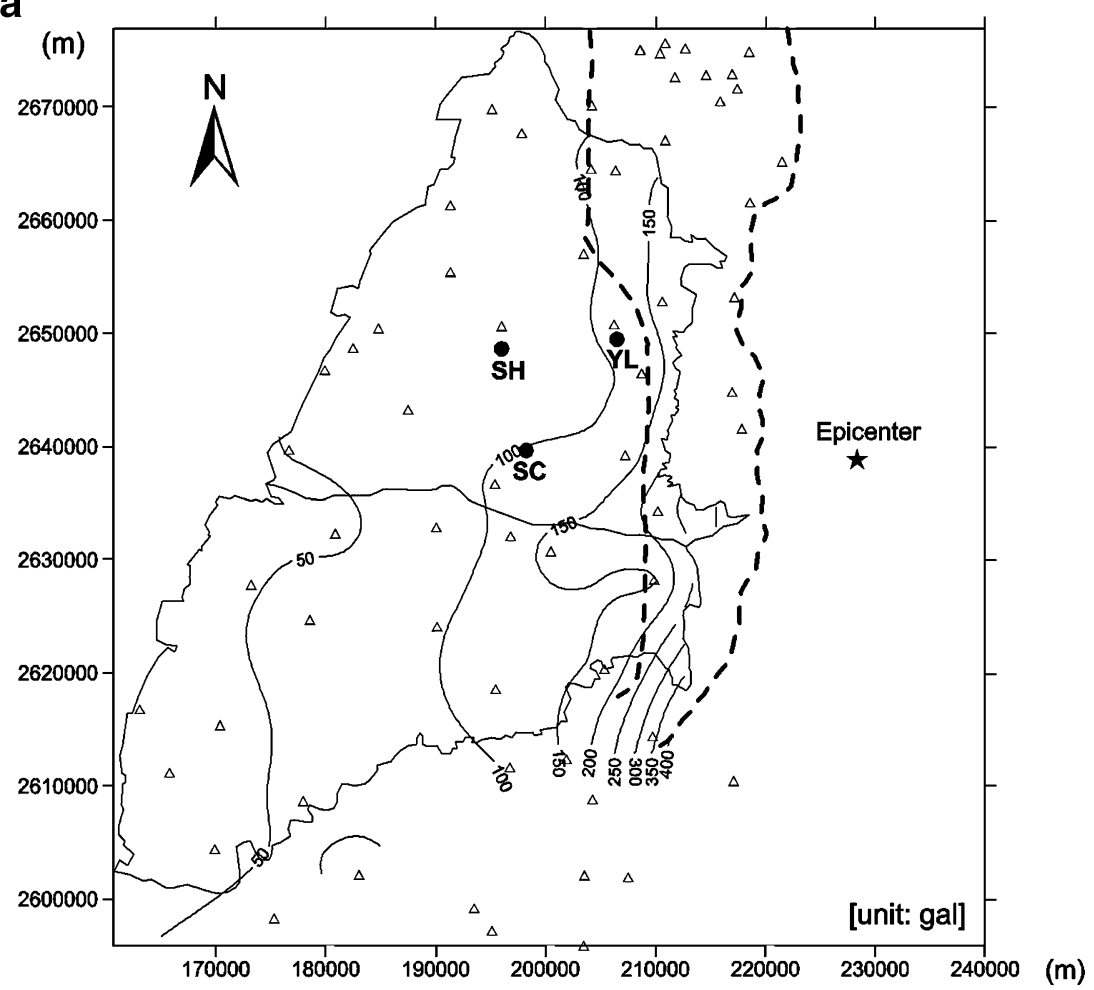

b

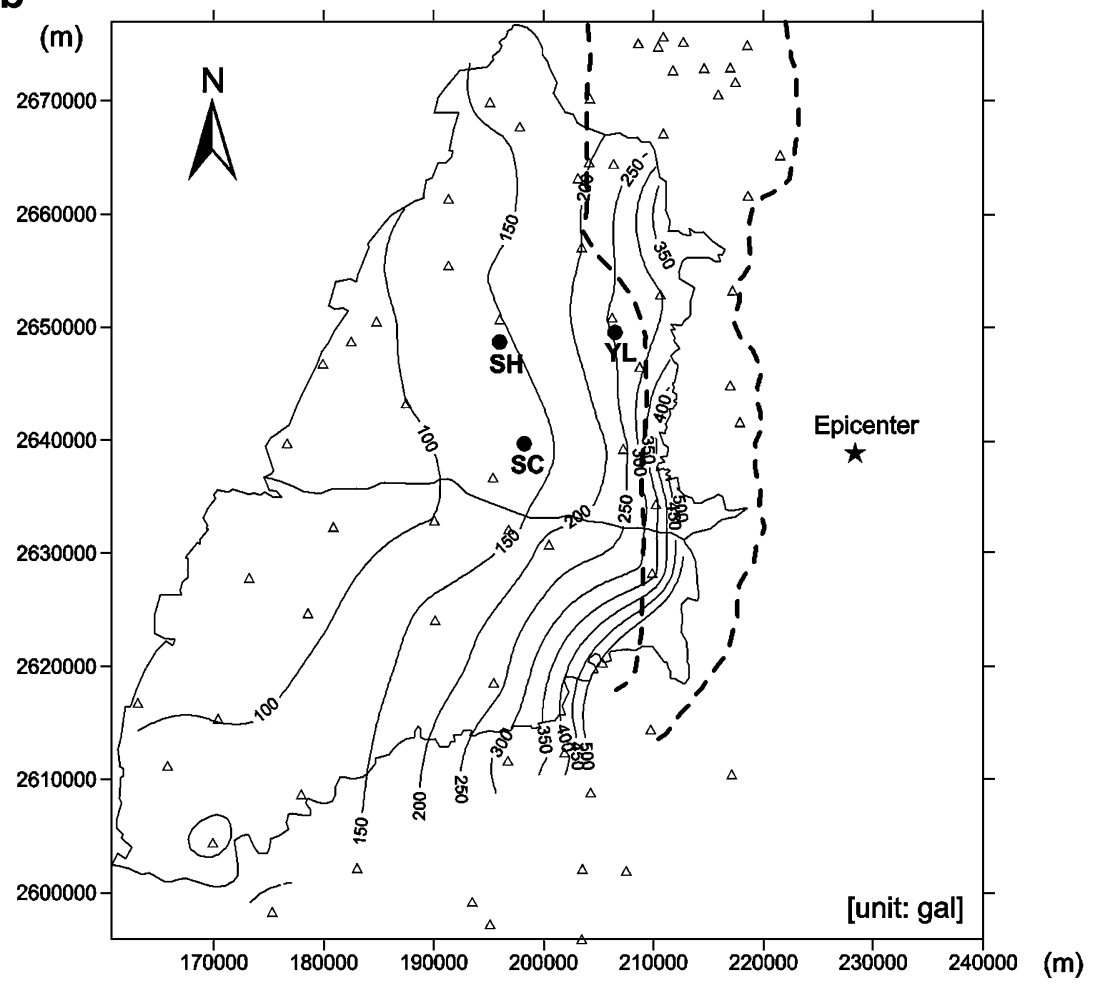

Fig. 6 Distributions of a vertical peak ground acceleration (PGA) and b horizontal PGA in relation to the 1999 Chi-Chi earthquake epicenter. The small triangles represent the seismic monitoring stations and the dashed lines are the faults. The unit gal equals $\mathrm{cm} / \mathrm{s}^{2}$. (Central Weather Bureau of Taiwan 1999) 
of the pre-earthquake $T_{\mathrm{yy}}$ and $T_{\mathrm{e}}$, respectively. The postearthquake $T_{\mathrm{xx}}$ decreases $36.6 \%$ of the pre-earthquake $T_{\mathrm{xx}}$. The earthquake also alters the original direction and magnitude of the pre-earthquake $T_{\mathrm{xy}}$, ranging from 0.15 to $-0.93 \mathrm{~m}^{2} /$ day. The post-earthquake $S$ reduced to $60.4 \%$ of the pre-earthquake $S$.

\section{Discussion}

Considering the three wells, the change between pre- and post-earthquake $\mathrm{T}$ ranges from increasing $61 \%$ (YL2) to decreasing $0.8 \%$ (SH2), and the change in $S$ is a decrease of approximately $60 \%$ at both $\mathrm{SC} 2$ and $\mathrm{SH} 2$. Although the post-earthquake change in $T$ at $\mathrm{SH} 2$ is smaller than that at $\mathrm{SC} 2$, the post-earthquake change in $S$ at $\mathrm{SH} 2$ is close to that at SC2. The analyzed result demonstrates that a threshold of $S$ is lower than that of $T$ for the earthquakeinduced aquifer deformation.

When the Chi-Chi earthquake occurred, vertical peak ground accelerations (PGAs) at $\mathrm{SH}, \mathrm{YL}$ and $\mathrm{SC}$ were approximately $80 \mathrm{gal}\left(\mathrm{cm} / \mathrm{s}^{2}\right), 115$, and 102 gal, respectively, (estimated from Fig. 6a) and horizontal PGAs at SH, YL and SC were roughly 145, 250 and, 140 gal, respectively (estimated from Fig. 6b). Therefore, the magnitude of the vertical PGAs at the three wells is consistent with the change in the post-earthquake $T$. That is, larger vertical PGAs produce greater changes in $T$.

$S$ is related to the compressibility of soil and water and can be expressed as follows (Freeze and Cherry 1979):

$S=\rho g b(\alpha+\eta \beta)$

where $\rho$ is the water density; $g$ is the acceleration of gravity; $b$ is the confined aquifer of thickness; $\alpha$ is the soil compressibility; $\beta$ is the water compressibility and $\eta$ is the soil porosity. This study assumed that $\beta$ remained constant and $\alpha$ was subject to change after the earthquake. The decreased post-earthquake $S$ measured at $\mathrm{SH} 2$ and $\mathrm{SC} 2$ indicates soil consolidation. This analyzed result is consistent with a compressional zone in the River Choushui alluvial fan where coseismic groundwater levels rose (Chia et al. 2001; Wang et al. 2001) and where a slight coseismic subsidence occurred (Yu et al. 2001).

According to Darcy's law, an increase of the postearthquake $T$ at YL2 and SC2 reveals that the velocity of groundwater flow is enhanced in the consolidated aquifers. The results of the anisotropic $T$ at $\mathrm{SC} 2$ can be exploited to demonstrate further this phenomenon after the Chi-Chi earthquake. The y-coordinate in Fig. 4 is virtually parallel to the Changhua fault (Fig. 1). The x-coordinate in Fig. 4 is almost perpendicular to the Changhua fault. The Chi-Chi earthquake led to a series of fault displacements. A field investigation and a GPS survey indicated that the hanging wall on the east side of the Chelungpu fault thrust northwestward. The displacement caused by the Chi-Chi earthquake increased northward, up to $4.2 \mathrm{~m}$ in the vertical direction and $7.1 \mathrm{~m}$ in the horizontal direction (Central Geological Survey of Taiwan 1999b). The plate between the Chelungpu fault and the Changhua fault moved westward to crush the plate on the western side of the Changhua fault. Thus, most vertical displacements of ground surface on the western side of the Changhua fault were downward, where the soil was compressed. Figure 7 displays a conceptual diagram regarding stresses in a small soil particle in the compressional zone. The normal stresses, $\sigma_{\mathrm{xx}}$ and $\sigma_{\mathrm{zz}}$, exerted on the soil, result in the decrease of the post-earthquake $T_{\mathrm{xx}}$ and $S$. The $\sigma_{\mathrm{yy}}$ is close to null owing to parallel to the faults. Thus, soil particles in the aquifer are swelled along the y-coordinate (that is, Poisson's ratio), causing the increase of the post-earthquake $T_{\mathrm{yy}}$. Moreover, when the Chi-Chi earthquake occurred, the coseismic groundwater levels rose under an undrained condition (Wang et al. 2001). The undrained Poisson's ratio is typically larger than the drained one (Wang 2000). Accordingly, the large lateral deformation significantly increases the equivalent $T$ and horizontal groundwater movement. Additionally, the normal and shear stress acting on soil alters the direction and the magnitude of $T_{\mathrm{xy}}$.

The post-earthquake changes in hydrogeological parameters have a great influence on spatiotemporal fluid pressure and horizontal groundwater movement (Doan et al. 2006). For example, in the pumping tests, upon the decrease of post-earthquake $S$ and no change in postearthquake $T$ at $\mathrm{SH} 2$, the increase of the pumping drawdown reveals that post-earthquake groundwater recharge is slower than pre-earthquake recharge owing to the reduction of aquifer storage (Fig. 5a). When the decrease of $S$ and the increase of $T$ occur at SC2 after the earthquake, the post-earthquake fitted lines of the pumping drawdown above the pre-earthquake fitted lines

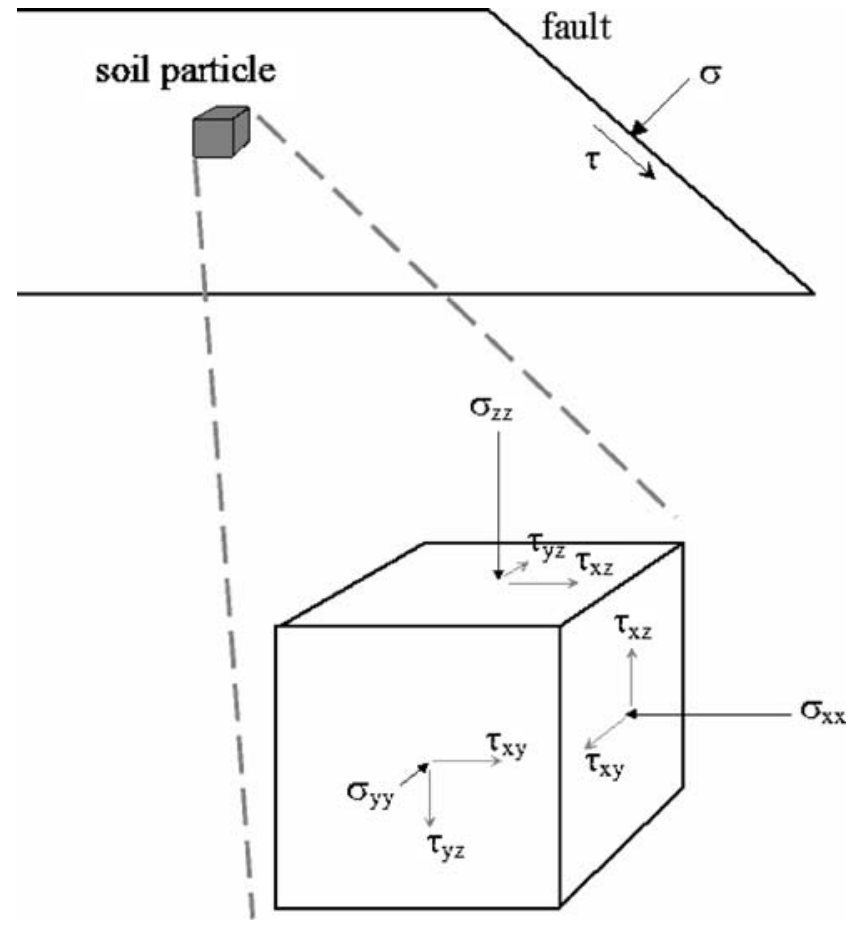

Fig. 7 Diagram of normal and shear stresses in a soil particle under the conditions found at the study site 
indicate that post-earthquake groundwater recharge is quicker than pre-earthquake recharge, in spite of the post-earthquake $\mathrm{S}$ being reduced (Fig. $5 \mathrm{c}-\mathrm{e}$ ). Thus, in terms of the groundwater recharge, a recharge effect on the enhancement of flow velocity outweighs the drawback of the decrease of aquifer storage. Additionally, the patterns of the post-earthquake pumping drawdown and $T$ changes at YL2 are similar to those at SC2, indicating that the $S$ at YL2 should be reduced after the earthquake.

\section{Conclusions}

This work explored aquifer parameters using pumping tests in the River Choushui alluvial fan before and after the 1999 Chi-Chi earthquake. Three wells, located in a compressional zone with high coseismic groundwater levels, were selected to examine likely changes in aquifer characteristics. Higher vertical PGAs more easily change aquifer properties. Moreover, a threshold of the aquifer deformation in $T$ is greater than that in $S$. Decreases in the postearthquake $S$ are roughly $60 \%$ at two of the wells (SH2 and $\mathrm{SC} 2$ ). The analytical outcomes indicate that aquifer soil is compressed and the aquifer storage capacity decreases after the Chi-Chi earthquake. Changes in the post-earthquake $T$ range from $61 \%$ increase to $0.8 \%$ decrease. An anisotropic $T$ tensor determined by a four-well pumping test at well $\mathrm{SC} 2$ further confirms that the earthquake-induced normal stresses consolidate soil particles, and soil particles are dilated laterally to increase the equivalent $T$ and groundwater movement. The post-earthquake changes in hydrogeological parameters have a great influence on spatiotemporal fluid pressure and horizontal groundwater movement. After the earthquake, a decrease of $S$ and an increase of $T$ decrease the pumping drawdown, whereas a decrease of $S$ and no $T$ changes increase the pumping drawdown. A pumping test is a very useful tool to explore changes in hydrogeological characteristics after and before earthquakes, especially performed using a multi-well pumping system which gives detailed information regarding the post-earthquake aquifer deformation.

Acknowledgements The authors would like to thank the National Science Council of the Republic of China for financially supporting this research under contracts Nos. NSC 92-2313-B-002-104 and NSC 93-2313-B-002-031.

\section{References}

Batu V (1998) Aquifer hydraulics: a comprehensive guide to hydrogeologic data analysis. Wiley, New York, pp 211-222

Brodsky EE, Roeloffs E, Woodcock D, Gall I (2003) A mechanism for sustained groundwater pressure changes induced by distant earthquakes. J Geophys Res 108(B8). DOI 10.1029/ 2002JB002321

Central Geological Survey of Taiwan (1999a) Project of Groundwater Monitoring Network in Taiwan during the first stage: research Report of Choushui River Alluvial Fan (in Chinese). Final report, CGS, Taiwan, 383 pp
Central Geological Survey of Taiwan (1999b) Geologic Survey of 921 Earthquake (in Chinese). Report No. 008414880101, CGS, Taiwan

Central Weather Bureau of Taiwan (1999) Seismic Record of 921 Earthquake. http://www.cwb.gov.tw.

Chia YP, Wang YS, Chiu JJ, Liu CW (2001) Changes of groundwater level due to the 1999 Chi-Chi earthquake in the Choshui River alluvial fan in Taiwan. Bull Seismol Soc Am 91:1062-1068

Cooper HH, Jacob CE (1946) A generalized graphical method for evaluation formation constants and summarizing well-field history. Trans Am Geophys Union 27(4):243-256

Doan ML, Brodsky EE, Ma KF (2006) In situ measurement of the hydraulic diffusivity of the active Chelungpu Fault, Taiwan. Geophys Res Lett 29. DOI 10.1029/2006GL026889

Freeze RA, Cherry JA (1979) Groundwater. Prentice-Hall, Englewood Cliffs, NJ, pp 58-62

Hsu KC, Tung CC (2005) On estimating the earthquake-induced changes in hydrogeological properties of the Choshuishi Alluvial Fan, Taiwan. Hydrogeol J 13:467-480

Lee M, Liu TK, Ma KF, Chang YM (2002) Coseismic hydrological changes associated with dislocation of the September 21, 1999 Chichi earthquake, Taiwan. Geophys Res Lett 29(17). DOI 10.1029/2002GL015116

Lin YB, Tan YC, Yeh TCJ, Liu CW, Chen CH (2004) A viscoelastic model for groundwater level changes in the Cho-Shui River alluvial fan after the Chi-Chi earthquake in Taiwan. Water Resour Res 40(4):W04213. DOI 10.1029/2003WR002412

Montgomery DR, Manga M (2003) Streamflow and water well responses to earthquakes. Science 300:2047-2049

Papadopulos IS (1965) Nonsteady flow to a well in an infinite anisotropic aquifer. Proceedings of Dubrovnik Symposium on the Hydrology of Fractured Rocks, International Association of Scientific Hydrology, Dubrovnik, Yugoslavia, pp 21-31

Roeloffs EA (1996) Poroelastic techniques in the study of earthquake-related hydrologic phenomena. Adv Geophys 37:135-195

Tokunaga T (1999) Modeling of earthquake-induced hydrological changes and possible permeability enhancement due to the 17 January 1995 Kobe earthquake, Japan. J Hydrol 223:221-229

Wang HF (2000) Theory of linear poroelasticity with applications to geomechanics and hydrogeology. Princeton University Press, Princeton, NJ, pp 54-55

Wang CY, Cheng LH, Chin CV, Yu SB (2001) Coseismic hydrologic response of an alluvial fan to the 1999 Chi-Chi earthquake, Taiwan. Geology 29(9):831-834

Wang CY, Dreger DS, Wang CH, Mayeri D, Berryman JG (2003) Field relations among coseismic ground motion, water level change and liquefaction for the 1999 Chi-Chi $(\mathrm{Mw}=7.5)$ earthquake, Taiwan. Geophys Res Lett 30. DOI 10.1029/ 2003GL018439

Water Conservancy Bureau of Taiwan (1995) Project of groundwater monitoring network in Taiwan during the first stage during 1992 to 1994: research report on the Choushui River Alluvial Fan (in Chinese). Midterm report, Minister of Economic Affairs, Administration Yuan, Taiwan, $350 \mathrm{pp}$

Water Conservancy Bureau of Taiwan (2000) Analysis of the changes of surface levels and groundwater levels caused by the 921 Chi-Chi Earthquake (in Chinese). Minister of Economic Affairs, Administration Yuan, Taiwan, $87 \mathrm{pp}$

Water Resource Bureau of Taiwan (2000) Application of the television inspection system to investigate the status of groundwater monitoring wells after the Chi-Chi Earthquake (in Chinese). MOEA/WRB-8900050, Minister of Economic Affairs, Administration Yuan, Taiwan, $302 \mathrm{pp}$

Yu SB, Kuo LC, Hsu YJ, Su HH, Liu CC, Hou CS, Lee JF, Lai TC, Liu CC, Liu CL, Tseng TF, Tsai CS, Shin TC (2001) Preseismic deformation and coseismic displacements associated with the 1999 Chi-Chi, Taiwan, earthquake. Bull Seismol Soc Am 91:995-1012 